\title{
Spatial configuration of Rostov agglomeration in southwestern Russia - territorial, demographical and functional dynamics
}

\author{
Vasilisa Gorochnaya ${ }^{1,2}$, Andrey Mikhaylov¹, 3 \\ ${ }^{1}$ Immanuel Kant Baltic Federal University, Kaliningrad, Russia \\ ${ }^{2}$ Southern Federal University, Rostov-on-Don, Russia \\ ${ }^{3}$ Saint Petersburg Electrotechnical University 'LETI', Saint-Petersburg, Russia
}

Cities around the world are central locations for economic activity, industrial production, research and innovation. Urban environment is a favourable locus for entrepreneurship and living, accumulating a significant share of regional and national administrative, financial and human resources, concentrating advanced public infrastructure and social sector services. In the process of regional development, the integration and coherence between cities strengthen, the functions are redefined, and the specialisation deepens, while the role of the central city(-ies) is reinforced. Consideration of inter-city intraagglomeration socioeconomic integrity and functional interconnectivity is vital for efficient governance. However, the blurred boundaries of urban agglomerations impede elaboration of place-specific development policies on urban and regional growth. Our study is aimed at delimitation of urban agglomeration structure around the Rostov-onDon - one of the ten largest cities of Russia and the administrative centre of the Southern federal district. Results suggest that Rostov agglomeration continues to evolve with a different level of integrity between city clusters of the three agglomeration arcs. We find that industrial clustering and transportation network determine the developmental trajectory of the urban agglomeration, shaping its spatial configuration and causing pathdependency.

Key Words: urban agglomeration, metropolitan area, city cluster, urban cluster, Russia

Article Info: Received: Fuly 7, 2020; Revised: November 10, 2020; Accepted: November 10, 2020; Online: November, 30, 2020.

\section{${ }^{*}$ Corresponding author}

Address: A. Nevskogo Str. 14, Kaliningrad, 236016, Kaliningrad region, Russia. Phone: +79052400526 / +74012465917 | Email: mikhailov.andrey@yahoo.com

(C)2020 Human Geographies; The authors 


\section{Introduction}

Cities are central places of economic growth. Over the past decades, cities experienced an intensive population increase and expanded on to suburban areas at an even more incredible pace (Angel et al., 2011). Urbanisation has become a worldwide phenomenon along with industrialisation, and it is projected to increase with the decline of agriculture and industry share of gross domestic product (GDP) values against the service sector, as well as the shift to a knowledgebased economy model - so desired by most countries. Scholars continuously register the profound effect of urbanisation on the cumulative role that cities have on socioeconomic, technological, and innovative development. Nowadays, cities generate nearly $80 \%$ of the world's GDP (Grübler \& Fisk, 2013). Thanks to the diversity of institutions, the accessibility of resources, and the availability of modern infrastructure, cities are fertile ground for growth and prosperity (Duranton \& Puga, 2004; Stolarick, \& Florida, 2006). The indirect influence of turbulent urban ecosystem on organisations and entrepreneurs fuels creativity, knowledge production and innovation (Johnson, 2008; Athey et al., 2008; Li et al., 2019). Cities are increasingly referred to as the locus for open innovation and an ecosystem that enables learning, cross-fertilisation, and innovation-driven collaborations between business, academia, government and the society (Ferraris et al., 2018; Almirall et al., 2014). As put by Florida et al. (2016:87), "[the] innovative activities are the products of cities and regions".

Based on the World Urbanisation Prospects report by the United Nations (2019), 55\% of the world's population already reside in urban areas, and by 2050 this share is expected to rise to $68 \%$. We are experiencing an influx of people, ideas, and capital (Hu, 2017; Johansson et al., 2018). Migration to cities is driven by the expectations of more significant career opportunities, higher living standards, better public infrastructure (Wang et al., 2019). Urban areas are attracting the most educated and talented individuals, entrepreneurs, and innovators (Beaverstock, 1994), as well as categories of people for whom migrating to big cities, is attractive despite the improving facilities in rural areas (Beauchemin \& Schoumaker, 2005). The parallel trends on globalisation and regionalisation reconfigure the spatial structure of industry value chains that cluster in hot spots around the globe (Deutschmann, 2019; Ye et al., 2019). This structure is organised around the 'world cities' deeply integrated into international labour division (Fang \& Yu, 2017; Tabuchi, 2013). However, the structural relationship within agglomerations changes over time. The spatiotemporal factor in developing agglomerations is accented in several recent studies (Butsch et al., 2017; Lu, 2019; McCann \& Van Oort, 2019; Sementsov et al., 2020). As cities develop, they change their internal structure, and the overall environment in which they are located transforms. Regional and national shifts in the economic system change the territorial socioeconomic system of agglomerations (Brail \& Hussey, 2018). Cities evolve due to the changing historical patterns: as Post-World War II revitalisation patterns become irrelevant, cities update around the new world paradigm led by demand from the 
younger generation for new standards of quality of life, creative work, time for leisure, and the demand for mobility, that is true for both urban and suburban areas (Tomalty \& Mallach, 2015). Despite the common worldwide trends, the changes in cities appeared and predicted to be different in developed and developing countries (Condon, 2019). National specificities, as well as peculiarities of the localisation and the genetics of historical development embodied in the constants of 'city geometry' and the division of functions between urban centres, influence these changes. Both the catalysing and inhibiting trajectories are possible, as some elements of previous structure contradict the desired changes (Mikhaylov et al., 2018).

Urban agglomeration is viewed to signify both socioeconomic integrity and functional interconnectivity. It acts as an area of complex interactions between people and institutions located in central and peripheral cities, as well as rural 'inbetween areas' (Boussauw et al., 2018; Fang and Yu, 2017; Verstraten et al., 2019). Spatiotemporal development trajectories of cities include both urban sprawl and the clustering of individual cities shifting the fuzzy boundaries of the agglomeration along the functional economic zones. In the process of regional development, the integration and coherence between cities strengthen, the functions are redefined, and the specialisation deepens, while the role of the central city(-ies) is reinforced. The development of urban areas is not limited to urban sprawl. Urban agglomerations are highly dynamic spatial elements that evolve and reconfigure throughout time. As noted by Wang (2002), a spatiotemporal path of a city implies the development of a metropolitan area, integration into an urban cluster, and transformation into an urban agglomeration. These development stages define the increasing complexity and geographical scope of a functional urban region (Chuanglin \& Danlin, 2017). Urban agglomerations are essentially a set of closely interconnected cities, whose ties are sustained by related population and economic activities (Ni, 2008). The greater strength and the higher the frequency of socioeconomic ties among the central and peripheral cities, the easier it is to organise networks and realise innovational spillovers. However, the inequality and deep changes of the intraagglomeration space and the principles of its interaction with the neighbouring territories cause profound difficulties for both the study and management of agglomerations, as their delimitation is problematic.

Blurring the border and defining only the perimeter reduces the effectiveness of urban management and regional growth strategies. The development and intensity of ties within agglomerations cause the need for the complex decisions and integrative strategy, taking into account all the spatial agglomerating system. One of the most urgent problems for both administrative and business governing of such spatial systems, as well as for the scientific-analytical process to provide the decision-making with the reliable data, is the issue of defining the border of agglomeration (Boix et al., 2011; Cattan, 2007). It can be incredibly difficult in the cases of polycentric spatial systems or highly centralised agglomerations with a heterogeneous set of cities due to their administrative status, historical status in 
the economic, culture and military sphere, as well as their size, growth rates and the character of relation with the centre.

However, we understand that cities come in a variety of forms, and this variety mirrors their management systems, as well as approaches to the delimitation of agglomeration boundaries. Changes in the perception of whether individual settlements are an integral part of an agglomeration influence the decisionmaking and the outcome of policy implementation. In our research, we proceed from the lessons learned from the studies mentioned above.

Firstly, the growth and expansion of cities contribute to the activation of socioeconomic and innovative processes not only in the intracity but also in the wider agglomeration space. This makes the process of agglomeration attractive from a regional development standpoint, but it can provoke problems in the development of settlements in the region that are not included in the agglomeration.

Secondly, the success of the socioeconomic and innovative development of actively growing urban agglomerations is determined and should be supported by the appropriate administrative-territorial management, taking into account new spatial realities. In this regard, it is vital to find a flexible approach to the delimitation of the boundaries of cities and urban agglomerations, which will make it possible to derive the most significant benefits from the growth of the connectivity of cities with each other and with surrounding rural settlements.

Thirdly, since urban agglomerations are characterised by high spatial and temporal mobility, the identification of their boundaries should be based on an assessment of territorial, demographic and functional dynamics. That is why it is essential to use the multi-scale approach to provide its delimitation, taking into account the fact that many agglomerations are still in the process of forming, while the administrative shaping of their borders, declared in policy documents against the de facto spatial-functional structure is harmful to the self-organising processes of their spatial modification and essential restructuring.

The aim of this study is to distinguish between the spatial elements of urban agglomeration depending on the functions they perform. We assume that they are complex structurally heterogeneous spatial systems formed over a long period as a result of the influence of a complex set of socioeconomic, infrastructural, and political factors. Our study uses the case of one of the largest and innovatively developed urban metropolitan areas of Russia - the Rostov agglomeration, located in the Rostov region, which is among the few in Russia to have its principles documented in regional policies (e.g. Strategy of socioeconomic development of the Rostov region for the period up to 2030). The Rostov metropolitan area is surrounded by a significant number of smaller satellite cities and follows a monocentric structural model. The functions of the satellite cities underwent significant transformations during the period of active growth of the core-forming city of the agglomeration - Rostov-on-Don. Moreover, Rostov is a historically large agricultural region with a high share of the rural population, which has retained agro-industrial specialisation in the structure of its economy. Therefore, this region is an excellent example for studying the role of rural 
settlements in agglomeration processes and transforming their functions, including from rural to urban. The study on the structure of the Rostov agglomeration is of significant conceptual value as it reflects a vivid example of the trend for the configuration of centralised urban agglomerations in the transition towards polycentricity, which also affects the redistribution of functions within the regional innovation system.

\section{Methodology}

For the purposes of this study, we will consider urban agglomeration as a spatial urban-rural system located within the framework of one administrative region and having close socioeconomic, scientific, educational, infrastructural, and political ties between its elements. The following delimitation criteria, presented in a comprehensive review of Fang and Yu (2017) must exist for outlining the agglomeration boundaries: a. the availability of a sizeable agglomeration-forming city that meets the following conditions: population exceeds one million people; there are a significant number of smaller cities around it connected by a developed transport network; location at the intersection of transport routes of various types of transport, it is a large transport and logistics hub; socioeconomic integration with satellite cities and neighbouring rural areas; b. a high level of urbanisation of the territory with an urban population of at least 50-75\%; c. recognition of the status of agglomeration in scientific research and policy documents; d. strong historically developed ties of the main city and neighbouring territories, resulting in a common regional identity; e. availability of transport corridors and high transport accessibility from the core of the agglomeration to the periphery - within 4 hours' drive; f. the connectedness of cities of the agglomeration with rural settlements; g. a variety of structural elements of the agglomeration, formally fixed by administrative-territorial division with a clear hierarchical structure; h. a significant cumulative volume of industrial production and retail trade within the boundaries of the agglomeration - the ration of about 70 and $45 \%$ of the region, respectively.

The study area is the Rostov agglomeration, which is located in the Rostov region of Russia around its administrative centre - Rostov-on-Don. At the NUTS3 statistical level, the Rostov region includes 55 municipalities: 12 urban districts (Rostov-on-Don, Azov, Bataysk, Volgodonsk, Gukovo, Donetsk, Zverevo, Kamensk-Shakhtinsky, Novocherkassk, Novoshakhtinsk, Taganrog, Shakhty) and 43 municipal districts. The lower administrative level of the region is represented by urban and rural settlements - local administrative units (LAU). Rural settlements consist of villages (poselok, selo, stanitsa). Urban settlements include cities and towns. The territory of an urban district includes one or more cities and/or urban-type settlements, and may also include rural settlements. Municipal districts may include both urban and rural settlements or are limited to rural settlements only. The administrative-territorial structure of the Rostov region has a centre-peripheral construction principle with a centre - a millionaire 
city of Rostov-on-Don and a distributed network of smaller cities: 6 large cities with a population of 100-250 thousand people (Taganrog, Shakhty, Volgodonsk, Novocherkassk, Bataysk, Novoshakhtinsk), 4 medium-sized cities of 50-100 thousand people (Kamensk-Shakhtinsky, Azov, Gukovo, Salsk), and 12 small cities of under 50 thousand people (Donetsk, Aksay, Belaya Kalitva, Krasny Sulin, Millerovo, Morozovsk, Zernograd, Semikarakorsk, Proletarsk, Zverevo, Konstantinovsk, Tsimlyansk), as well as 6 urban-type settlements with a population comparable to small towns. All large and medium-sized cities apart from Salsk have the status of administrative centre in the eponymous urban districts (consisting of 1 city), similar to urban district Rostov-on-Don, which is the administrative centre of the Rostov region. The rest of the cities are administrative centres in the municipal districts of the region. Note that in several municipal districts the functions of an administrative centre are performed by a village or a settlement, not a city.

The delimitation of Rostov agglomeration was made by applying a multihierarchal research design. At the first stage, we provided an overview of the historical background behind urbanisation dynamics and the functions of cities within the standard socioeconomic and socio-cultural system. The key points are outlined by the main shifts that caused the changing of the whole agglomeration space. Empirical evidence on the population dynamics of all the cities analysed is traced from 1896 to 2019 - the latest date of the statistical bulletin, illustrating the main stages of the agglomeration process. The data from official statistics are analysed through the moment dynamic data series - five intervals of 30 years, as well as the growth rates calculated both for each of the cities under consideration and for the total agglomeration. The method of statistical extrapolation is applied for some years with missing information. The population growth rates are mapped and compared with the facts of emerging and growing trade and logistics facilities, settlements and recreational areas, large enterprises and higher education institutions, as well as their clustering trends, which intensify intraagglomeration interactions. The inclusion of Shakhty, Novoshakhtinsk and Volgodonsk into the research area for evaluating the territorial system of the Rostov agglomeration is an unusual approach (Druzhinin, 2013; Merinov \& Merinova, 2014; Bredikhin, 2016; Andreyeva, 2011; Abdullaev \& Mishchenko, 2017). However, we believe this will increase the accuracy of research and enable us to track the development trends of the first and second agglomerations arcs more fully, taking into account the presence of a geographically remote third arc at the North-East.

At the second stage of the study, a multilevel approach to delimiting the Rostov agglomeration with the allocation of 3 agglomeration arcs and 2 conurbations was applied, using the findings of the spatial location and connectivity of the cities held at the first stage of the study. The inclusion of Shakhty, Novoshakhtinsk, and Volgodonsk in the urban spatial system of the Rostov agglomeration represented the novelty of the study and enabled to grasp its development trends in its development. At this stage, the parameters of the modern Rostov agglomeration were assessed as of the end of 2019. Firstly, the urbanisation level of the Rostov 
agglomeration is estimated by the share of the urban population. Secondly, the total volume of industrial production and retail within the boundaries of the agglomeration was calculated.

Thirdly, the transport connectivity of the cities of the Rostov agglomeration was estimated based on the analysis of data on the distance between Rostov-onDon and other cities, as well as the time it takes to cover the distance by car and public transport.

Fourth, an assessment of the status of the agglomeration in the scholarly literature and in policy documents has been carried out.

\section{Research results}

\section{The formation of the Rostov agglomeration}

The Rostov-on-Don, as the centre of the agglomeration, had the most active growth in 1930-1950 when large knowledge-intensive industries have emerged, sculpting its modern-day economic profile. Mostly these included agricultural technologies, agricultural engineering, and processing of agricultural products. The military industry is also traditional for the Rostov-on-Don, namely the naval and the helicopter industry of the military-industrial complex. The intensive production and technological growth of the 1950s and 1980s gave an impetus for population growth (Figure 1).

Rostov-on-Don has attracted both the economic resources from the agricultural sector and the human resources from the surrounding territory of the region, contributing to the growth of the city and the integrity of the neighbouring settlements. Integration and intensification of contacts between Rostov-on-Don and other regional settlements have formed a large labour market centred on the Rostov. The nearest towns of the first agglomeration arc have also experienced population growth. Agglomeration externalities affected Bataysk with intensive population growth during 1920-1950.

This satellite city functions as a transport and logistics node, while Rostov-onDon occupies the role of a multi-modal transport hub. Apart from the spatial proximity to the centre, the extensive growth rates were determined by lower real estate prices as compared to Rostov-on-Don. This factor is still evident nowadays when the quality of new residential properties in Bataysk and its transport accessibility from/to Rostov-on-Don has improved.

Rostov-on-Don is subjected to urban sprawl; covering with urbanisation new areas towards Western, Northern, and Eastern directions. From the South, the expansion of the city stopped by the river. As a result, in the situation of traffic jams, that are often the case, drive to the downtown of Rostov-on-Don is complicated. In this case, Bataysk appears to have a better location than the outskirts of Rostov, which became especially evident after the reconstruction of bridges over the Don River. 


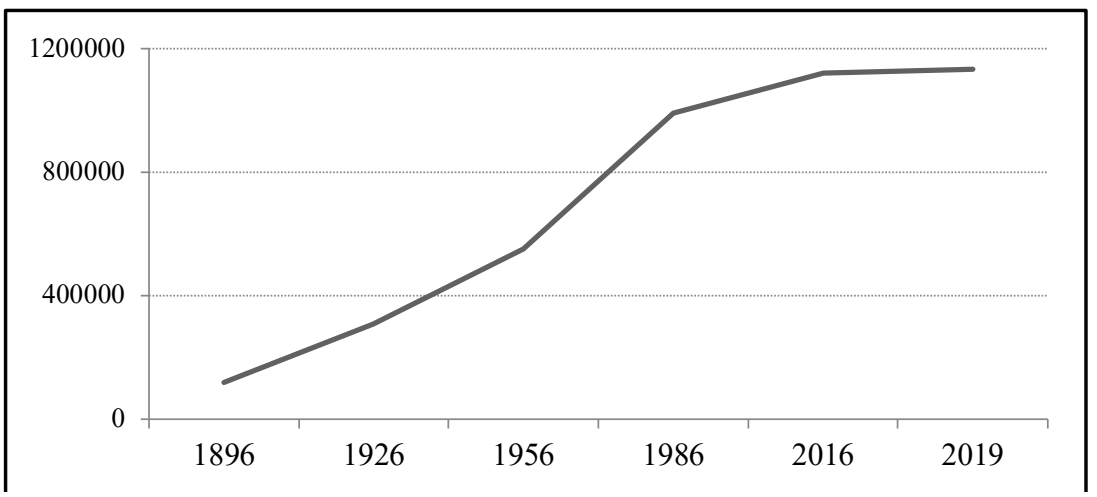

Figure 1. Population growth in Rostov-on-Don, people.

Source: The Russian Federal State Statistics Service - Rosstat
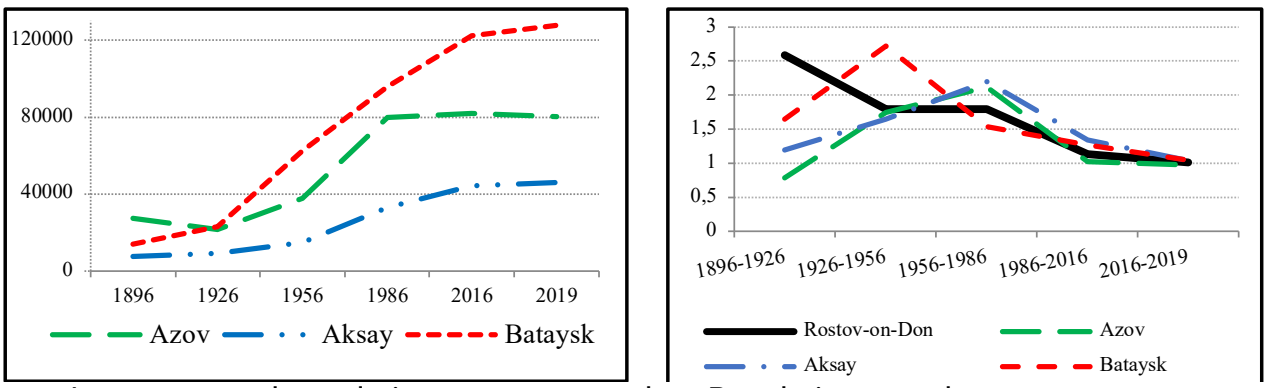

a. Average annual population

b. Population growth rate

Figure 2. Population dynamics in the first agglomeration arc of the Rostov agglomeration and comparative growth rates.

Source: The Russian Federal State Statistics Service - Rosstat

The complex industrial zone on the left bank of the river with port logistics built between 2000-2010 gained a new development impetus in 2017-2018 with new infrastructural projects, including a recreational space on the right bank of the river. Industrialisation and urbanisation along the riverbanks shortened the distance between Rostov and Bataysk (Figure 2).

While Bataysk started an active growth before the 1950s, Aksay - another satellite city of Rostov-on-Don had an impetus of growth during 1950-1980 thanks to the important transport highways passing in the Eastern direction from Rostov. Currently, it tends to gradually merge with Rostov-on-Don by covering the in-between spaces with extensive industrial and wholesale facilities along the highway linking the two cities. Some essential industries have relocated from Rostov-on-Don to Aksay and the neighbouring Aksaysky district, such as "Atlantis Pak" producing wrapper for food products, and "Yug Rusi" (the trademark "Golden Seed") - one of the member companies of the agricultural production cluster. Lately, the cluster is diversifying to include the maritime sector, featuring the port logistics complexes both in the left bank industrial zone of Rostov-onDon and upstream of the Don river in Aksaysky district.

Another city of the first agglomeration arc is Azov, which is older than Rostovon-Don and historically was a Turkish fortress before it became Russian at the 
turn of XVII-XVIII centuries. The growth of Rostov-on-Don was firstly 'fed' by the migration flows from Azov, which derived from the population statistics before the 1930s (unlike the positive dynamics of Bataysk and Aksay). Later, during 1930-1980, it embedded itself into the system of satellite cities around Rostov-onDon and inherited the inductive growth against the periphery, following the development dynamics of the core. Since 1990, the growth rate in Azov once again became lower as it is quite remote compared to Bataysk and Aksay, losing in the quality of life and urban infrastructure. However, some important agricultural industries are still located in Azov, such as food processing, machinery and light manufacturing, as well as port logistics. Most companies are the recipients of the technologies produced in Rostov-on-Don. Located in the agglomeration arc of Rostov, unlike other satellite cities, Azov maintains comparatively independent production, depending on the centre of agglomeration only in terms of technological growth and business environment.

The cities of the second agglomeration arc are much more independent in both a production and technological sense, but they are also interrelated with the agglomeration core by the intensive migration and financial flows. Taganrog is a coastal city (older than Rostov-on-Don, founded at the end of the XVII century), having a port complex in Azov sea. Its production profile includes a wide range of industries, and most of them are associated with the military and maritime activities. The high level of some technologies developed and used here, is converted into the civil industries. The city has a comparatively high educational and scientific potential. In 2006, the Southern Federal University was established as a result of the integration of 4 institutes, including the Taganrog Radio Engineering Institute, one of the most innovative higher education institutions in the Rostov region featuring a strong collaboration with local businesses. This integration enforced the interrelation between Rostov-on-Don and Taganrog via migration flows, exchange of students, teachers, and technologies. The A.P. Chekhov Taganrog Institute became part of Rostov Economic University.

The next impetus to integration was the import substitution policy introduced by the federal government after 2014. The local educational and R\&D potential enabled the formation of some hi-tech clusters with their centre in Taganrog and subcontracts in Rostov-on-Don (such as "Maritime Systems" providing fish search echolocation equipment). Some clusters that emerged in Rostov-on-Don have their branches in Taganrog (e.g. "South Constellation", based at Southern Federal University, who provides a wide range of hi-tech machinery production, including for the maritime economy).

Despite the currently enforcing production and technological status within the agglomeration, Taganrog stagnated in population growth after the 1980s, although outperforming other cities in the agglomeration (Figure 3). Population moves to Rostov-on-Don against numerous measures to reanimate local production, enforce networking with industries of the agglomeration core, and the support for the inflow of technologies. Taganrog is a vital part of the agglomeration and cultural capital of the Rostov region, having many objectives of cultural heritage, a well-developed cultural life and strong traditions. 


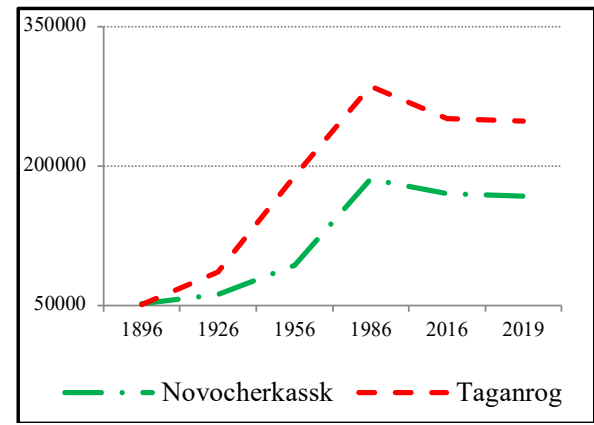

a. Average annual population

Figure 3. Population dynamics in the second agglomeration arc of the Rostov agglomeration and comparative growth rates

Source: The Russian Federal State Statistics Service - Rosstat

Similar trends and peculiarities are found in Novocherkassk - another city within the second agglomeration arc. The city was founded in 1805 (and, according to the city plan, it is built as a smaller copy of Paris) and became an unofficial capital of Don Cossacks. Now it is the centre of Cossack culture. Large power plants are located here, such as the Novocherkassk power plant. The range of industries includes engineering, metallurgy, aviation, electric power, chemical (including oil and gas), food and light industries (as opposed to heavy industry), and since the $2000 \mathrm{~s}$ - the production of glass bottles and containers. Science and education are also developed, with the Platov South-Russian State Polytechnic University, as well as several scientific and R\&D institutions. Novocherkassk State Reclamation Academy was integrated into in 2013 into the Don State Agrarian University with the centre in Persianovskaya that enforced the interaction of Novocherkassk with its neighbourhood. There is also strong academic, social and business interrelation with Rostov-on-Don, despite Novocherkassk independence being similar to Taganrog. In recent years the relocation of the airport from the Rostov-on-Don closer to Novocherkassk 'shifted' the territorial accents within the agglomeration space. Nevertheless, at the same time, the city population did not grow; it only migrated to the agglomeration centre.

The third arc of the Rostov agglomeration includes mainly small mono-profile cities that are still growing (although, at a slow pace since 1980). Shakhty and Novoshakhtinsk are settlements of miners who are in economic and social crisis after the decline of the mining industry in the region. Nowadays, this area is trying to diversify its specialisation and improve infrastructure, which necessitates intensive technological, financial, and productive interaction with Rostov-on-Don. It also mainly depends on Rostov as an educational centre with the goal of improving the quality of human capital. The flows of student migration coincided with the creation of branches of Rostov universities in Shakhty.

Volgodonsk is a young city founded in 1950. It evolved thanks to the active development of water transport and, after full-scale construction, became a placement area of new industries in the region, primarily in chemical production. The primary stimulus for the development of the city was, however, the construction of a nuclear power plant in close cooperation with scientific and 
research organisations of Rostov-on-Don. Additional opportunities for interaction with the agglomeration centre was air communication between the two cities, which existed until the 1990s. At present, nuclear energy, along with relevant industries and infrastructure, is the main area of employment. Therefore, the limited labour market causes intense competition; and, although the population growth is provided by migration from neighbouring rural areas, the majority of the young generation of Volgodons try to find work in Rostov-on-Don after studying in Rostov (Figure 4). Analysing the periods of agglomeration development, we observe some changes in its landscape over the past century along with the constant growth of Rostov-on-Don. Consequently, the agglomeration elements have changed their proportions (Figure 5).

High growth rates of the third agglomeration arc were caused by the development of the mining industry and fell due to the industrial crisis. The transition to the first and second arcs was caused by the growth of Rostov-on-Don, as well as the development of new industries, logistics, and settlement systems.

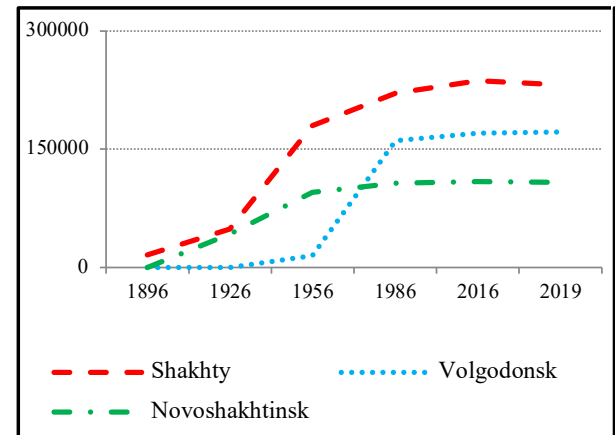

a. Average annual population

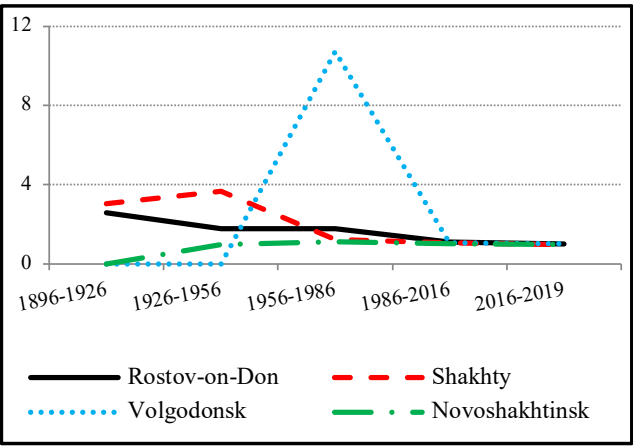

b. Population growth rate

Figure 4. Population dynamics in the third agglomeration arc of the Rostov agglomeration and comparative growth rates.

Source: The Russian Federal State Statistics Service - Rosstat

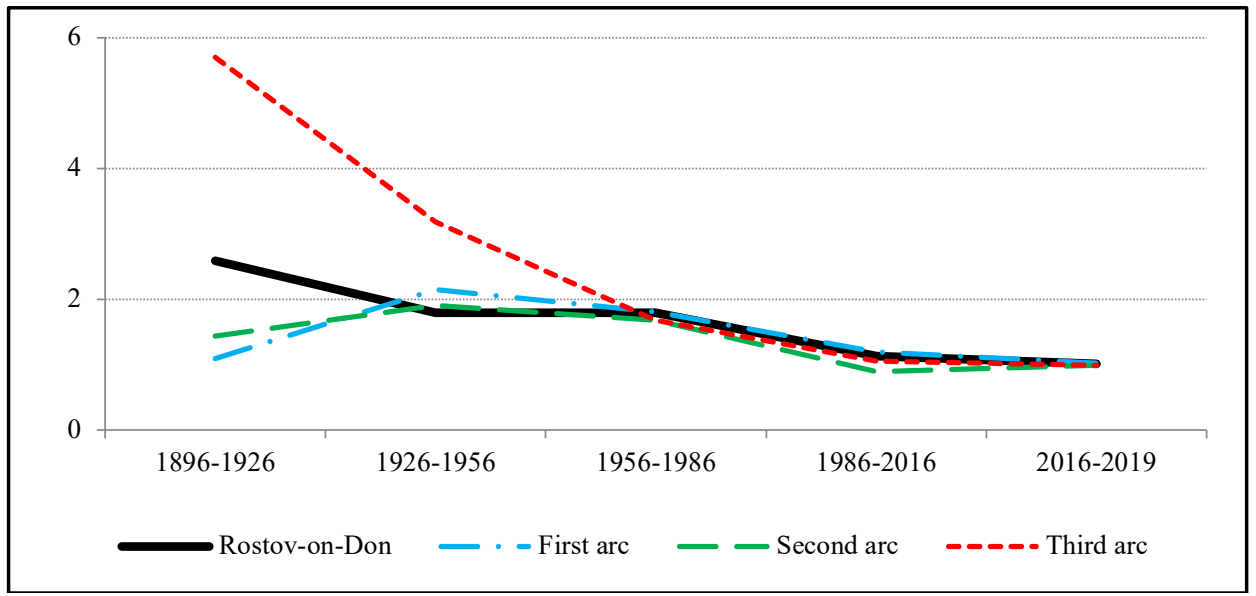

Figure 5. Growth rates of all the agglomeration arcs within Rostov agglomeration Source: The Russian Federal State Statistics Service - Rosstat 
Furthermore, as shown by the data, the growth rate is currently being synchronised and reduced, which indicates that the Rostov agglomeration is slowing its extensive growth and requires intensive changes. Throughout the period under review, both the center and the periphery of the agglomeration pulled and collected natural and human resources from the rest of the region. This trend has led to the overall development of the agglomeration, including its locally important nodes and small satellite towns. In turn, the periphery of the agglomeration fed the centre through a further transfer of resources and new waves of migration, stimulated by the growth of spatial inequality in the development of infrastructure and quality of life. This trend mainly affects the cities of the second agglomeration arc, and in the cities of the third arc, it is partially offset by further migration from the countryside.

\section{Modern Rostov agglomeration}

The concept of the Rostov agglomeration is enshrined in the strategic documents for the development of the Rostov region (Strategy for the socioeconomic development of the Rostov region for the period until 2030, the Concept of territorial planning of the Rostov region), and the agglomeration level is highlighted along with the regional level of planning. The spatial structure of modern Rostov agglomeration is a complex multi-element system, including the core-forming city of Rostov-on-Don, three agglomeration arcs - Chaltyr-Aksay, Taganrog-Novocherkassk, and Novoshakhtinsk-Volgodonsk, and two conurbations - Shakhty and Kamensk-Donetsk (Figure 6).

The process of pulling the population into the cities of the Rostov agglomeration continues, which is accompanied by an increase in its population share of the Rostov region (Table 1). By the beginning of 2020, more than $80 \%$ of the entire urban population of the region is concentrated in the Rostov agglomeration, half of which live in Rostov-on-Don. The primary growth is provided by the Rostov-on-Don and cities of the first agglomeration arc, adjacent to it. Currently, cities of the first agglomeration arc have become the most attractive for intra-regional migration, since they have more favourable living conditions against the background of lower housing prices. In terms of retail turnover, cities of the first agglomeration arc account for $16.7 \%$ of the total turnover in the region, which is significantly higher than for the second and third agglomeration arcs and correlates with the distribution of the urban population. In general, the Rostov agglomeration is the main driver for the development of the industry and services sector of the region, providing $66.9 \%$ of all manufacturing output and $77.3 \%$ retail turnover. 


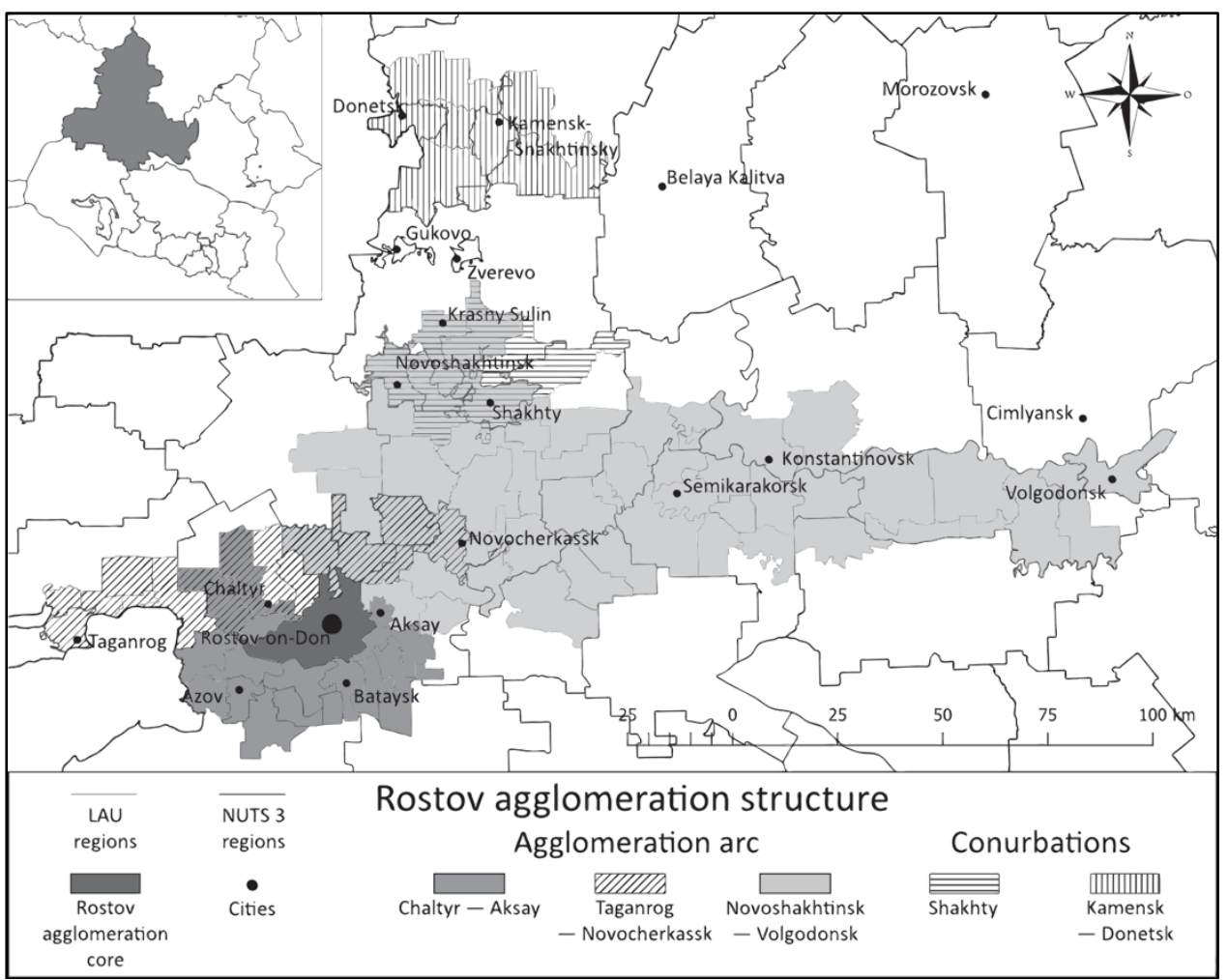

Figure 6. Spatial urban system of the Rostov agglomeration. Source: Mikhaylov et al., 2020

Table 1. The share of the Rostov agglomeration in the region in terms of agglomeration development (\%)

\begin{tabular}{cllllllll}
\hline Agglomeration elements & 2013 & 2014 & 2015 & 2016 & 2017 & 2018 & 2019 \\
\hline \multicolumn{7}{c}{ Average annual population } \\
Core & 25.9 & 26.1 & 26.3 & 26.4 & 26.6 & 26.8 & 27.0 \\
$1^{\text {st }}$ arc & 7.1 & 7.2 & 7.3 & 7.4 & 7.5 & 7.6 & 7.7 \\
$2^{\text {nd }}$ arc & 10.1 & 10.1 & 10.0 & 9.9 & 9.9 & 9.9 & 9.9 \\
$3^{\text {rd }}$ arc & 12.2 & 12.2 & 12.2 & 12.2 & 12.2 & 12.2 & 12.2 \\
Total & 55.3 & 55.6 & 55.8 & 56.0 & 56.2 & 56.5 & 56.8 \\
& Including urban population & & & \\
Core & 38.3 & 38.6 & 38.7 & 39.0 & 39.2 & 39.4 & 39.6 \\
$1^{\text {st }}$ arc & 8.4 & 8.4 & 8.5 & 8.6 & 8.7 & 8.8 & 8.8 \\
$2^{\text {nd }}$ arc & 14.9 & 14.8 & 14.8 & 14.7 & 14.6 & 14.6 & 14.5 \\
$3^{\text {rd }}$ arc & 18.0 & 18.0 & 17.9 & 18.0 & 17.9 & 17.9 & 17.8 \\
Total & 79.6 & 79.8 & 80.0 & 80.3 & 80.4 & 80.6 & 80.8 \\
& Manufacturing industry & output & & \\
Core & 39.5 & 36.5 & 41.6 & 43.5 & 41.9 & 35.5 & 32.4 \\
$1^{\text {st }}$ arc & 5.2 & 6.6 & 6.6 & 6.0 & 6.2 & 6.0 & 6.8 \\
$2^{\text {nd }}$ arc & 18.9 & 21.7 & 16.5 & 15.0 & 15.9 & 19.8 & 20.5 \\
$3^{\text {rd }}$ arc & 10.0 & 9.3 & 7.8 & 6.7 & 6.2 & 6.3 & 7.2 \\
Total & 73.7 & 74.1 & 72.5 & 71.3 & 70.3 & 67.6 & 66.9 \\
\multicolumn{7}{c}{ Cotail trade turnover per person } & & \\
Core & n/a & n/a & 42.1 & 42.5 & 40.6 & 42.1 & 42.7 \\
\hline
\end{tabular}




$\begin{array}{clllllll}1^{\text {st }} \text { arc } & \text { n/a } & \text { n/a } & 18.6 & 19.1 & 18.7 & 17.8 & 16.7 \\ 2^{\text {nd }} \text { arc } & \text { n/a } & \text { n/a } & 8.7 & 8.8 & 9.4 & 9.2 & 9.3 \\ 3^{\text {rd }} \text { arc } & \text { n/a } & \text { n/a } & 8.8 & 8.4 & 8.5 & 8.3 & 8.6 \\ \text { Total } & \text { n/a } & \text { n/a } & 78.1 & 78.8 & 77.2 & 77.4 & 77.3\end{array}$

Source: Rosstat regional office of Rostov Region. The main indicators of the socioeconomic situation of municipalities and Database of indicators per municipalities.

A significant contribution to the development of the Rostov agglomeration was made by the development of the regional transport system (Figure 7). In 2020, the time of getting from Rostov-on-Don to the most remote cities (Tsimlyansk, Morozovsk, Volgodonsk) by car does not exceed 3.5 hours, and 5 hours by public transport. The cities of the first agglomeration arc have the most excellent transport accessibility from the core of the agglomeration, as the journey takes no more than 40 minutes by car and 1.5 hours by regular bus. The most compact relative to the agglomeration core is Bataysk, which is in 19 minutes' drive, making it de facto another residential area of Rostov-on-Don.

Cities of the second agglomeration arc also have good transport connectivity with Rostov-on-Don within a 1-1.5 hours' drive. This is somewhat less preferable for labor migration in comparison with the cities of the first arc, however, it allows to establish a cargo flow between the cities of the agglomeration.

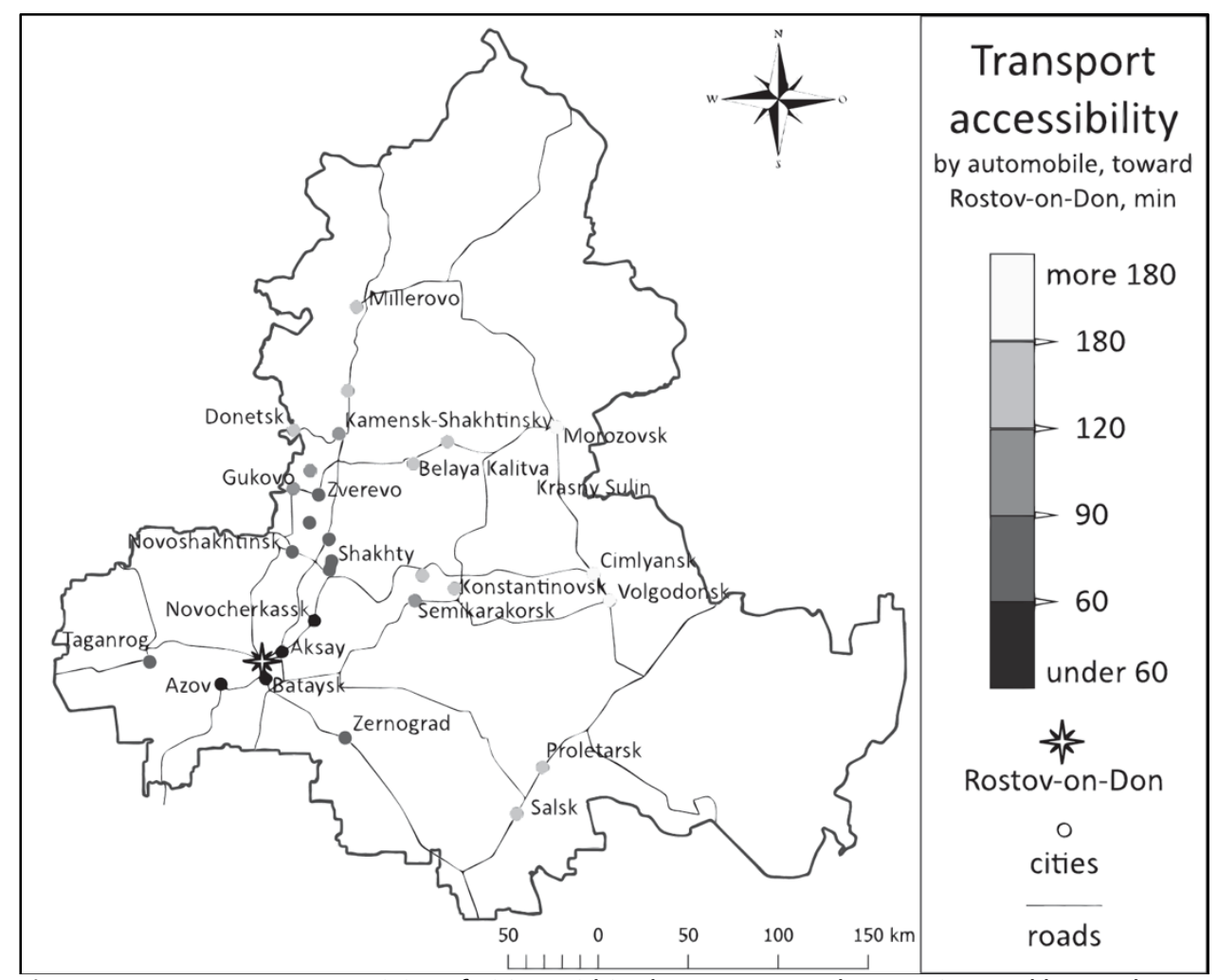

Figure 7. Transport connectivity of cities within the Rostov agglomeration and beyond Source: Mikhaylov et al., 2020 
The third agglomeration arc is strongly extended to the east of the region, so it has both cities close to Rostov-on-Don (1.5 hours by car to Novoshakhtinsk and Shakht) and remote ones (3.5 hours to Volgodonsk). Along with the functional connection between cities of the agglomeration, the evolution of administrativeterritorial units in the region is also essential to take into account, as during various historical periods the cities were included into various administrative systems. In 1930, Rostov-on-Don was the centre of the North Caucasus region, which included: 7 national autonomous regions, 10 autonomous cities and 87 administrative districts. In 1933 the Presidium of the Central Executive Committee decided to form the Northern region with the centre in Millerovo within the North Caucasus region. The further division contined in the South: in 1934 the North Caucasus region was divided into the Azov-Black Sea region (with the centre in Rostov-on-Don), and the North Caucasus region (with the centre in Pyatigorsk), and in 1937, the Azov-Black Sea region was divided into the Rostov region with the centre in Rostov-on-Don and the Krasnodar territory with the centre in Krasnodar, so it enforced the position and administrative role of Rostovon-Don. At that moment Rostov region included 7 cities of regional subordination (Rostov-on-Don, Kamensk-Shakhtinsky, Krasny Sulin, Millerovo, Novocherkassk, Taganrog and Shakhty), 2 cities of regional subordination (Azov and Salsk) and 61 administrative districts. This administrative division remained unchanged until 1953 (Kovalev et al., 2006).

In 1954 the Kamensk region was separated from the Rostov region with the center in Kamensk-Shakhtinsky. 32 districts were assigned to the Kamensk region, including several territories from the Voronezh region and 8 cities. In 1955, the city of Gundorovka was renamed Donetsk, also the city of Gukovo was re-formed. These decisions enforced the links within this group of cities. At the same period, Rostov region included 32 districts and 7 cities: Rostov-on-Don, Taganrog, Novocherkassk, Bataysk, Azov, Salsk and Zernovoi (now Zernograd). In 1957 Kamensk region was abolished, its territory was shared between the Rostov, Voronezh and Stalingrad regions (Kovalev et al., 2006).

Between 1958 - 1996 various administrative and territorial changes took place in the Rostov region, but they mostly related to changes at the rural district level, there was transformation, consolidation, renaming of districts. Also, a number of former villages and workers' settlements of the Rostov region received the status of cities, including Volgodonsk, Konstantinovsk, Aksay, Gukovo, Belaya Kalitva, Tsimlyansk, Proletarsk, Semikarakorsk. An important event in the administrative and territorial structure of the Rostov region was the adoption of the new Charter of the Rostov region in 1996 by the regional Legislative Assembly, which consolidated the administrative and territorial structure of that time. After amendments in 2001, the Rostov region included 55 administrative-territorial units. This administrative-territorial structure of the Rostov region existed until 2005, and then, after the changes in the borders of municipalities (rural and urban settlements, municipal districts, urban districts), the status of some localities was changed. As a result of the reform, as of January 1, 2005, 12 urban districts, 43 municipal districts, 18 urban settlements, and 390 rural settlements were 
formed in the system of territorial organisation of the Rostov region (Kovalev et al., 2006). So, the whole process of the evolving administrative-territorial division led to the superior administrative role of Rostov-on-Don. Also, the enforcement of its satellites took place, with them gaining the status of cities, while the previously important role of Millerovo and other remote centres became more and more peripheral.

\section{Discussion and conclusion}

Urban agglomerations as a spatial form of organising intercity space are becoming widespread around the globe. There are considerable differences between individual agglomerations in terms of the number of people concentrated in them and the administrative structure, which creates diverse patterns of spatial structure. Our research studied the structural features of a single-core urban agglomeration depending on the functions that its elements perform. In the process of a retrospective analysis of the formation of one of the largest Russian agglomerations - Rostov agglomeration, we confirmed the thesis that agglomerations are complex structurally heterogeneous spatial systems formed under the influence of a set of socioeconomic, infrastructural, political factors.

The modern Rostov agglomeration, contrary to the traditional notions of urban monocentric agglomerations developing in concentric waves of uniformly expanding systems, is a spatial-territorial form consisting of a core and three functional agglomerative arcs stretching along transport routes. The cities of the first "Chaltyr-Aksay" arc are closest to the core, territorially and in terms of socioeconomic development. At the initial growth of the Rostov agglomeration, they primarily participated in the formation of a single labour market for the central city of Rostov-on-Don, simultaneously using its educational, scientific, and technological achievements. Today, their functions have changed. Undoubtedly, the leading role of these cities in labour pendulum migration of Rostov agglomeration remains. However, this happens against the background of their independent socio-economic development. Thanks to active housing construction, reconstruction and the construction of transport infrastructure (roads, bridges), more favourable living environment and the density of social infrastructure in comparison with some areas of Rostov-on-Don, the cities of the first agglomeration arc are now an attractive place to live for the Rostovites themselves. Also, industrial unloading of Rostov-on-Don takes place due to the partial shift of production to its satellite cities from the first agglomeration arc, thereby reducing the maximum concentration of economic activity in the core of the agglomeration and gradually involving neighbouring cities in the suburbs of the millionaire city.

The cities of the second agglomeration arc "Taganrog-Novocherkassk", are more geographically distant from the core, perform the functions of a clusterindustrial and scientific-technological centre (in cooperation with Rostov-onDon). The availability of educational, scientific, technological, and industrial 
potential at Taganrog made it possible to form a secondary pole of agglomeration in the west of the region, although it is much smaller than Rostov-on-Don.

The "Novoshakhtinsk-Volgodonsk" agglomeration arc is the longest of the three, encircling the region from west to east. Its development is determined by the economic feasibility of using natural resources in the development of many industries in the region related to mining, energy, and transport (primarily water). Volgodonsk, the most remote city of the third agglomeration arc, is the only city in the Rostov region, except for the cities of the first agglomeration arc, that shows population growth, characterising it as another emerging growth pole within the Rostov agglomeration. Also, according to the results of the study, two small conurbations of Shakhty and Kamensk-Donetsk were identified, which are an accumulation of similar-sized cities with transport, logistics, and industrial significance in the region.

Thus, the active outsourcing of human resources from neighbouring rural and urban municipalities has ensured the extensive development of the monocentric Rostov agglomeration in the past. Nowadays, the tendency of reverse dynamics was observed, displaying a weak tendency toward decentralisation with the allocation of small secondary growth poles in the region.

\section{Acknowledgement}

The reported study was funded by RFBR according to the research project № 18310-20016 "Coastal cities in innovation spaces of the European part of Russia". Vasilisa Gorochnaya expressed her gratitude to the 5-100 competitiveness program of the Immanuel Kant Baltic Federal University for supporting her research fellowship.

\section{References}

Abdullaev, R.A. and Mishchenko, K.N. (2017), "A research into the theoretical and methodological foundations of the concept of regional spatial development and the formation of growth poles of the Rostov oblast" (in Russian), Regional Economics: Theory and Practice, vol. 15, no. 5, p. 802-813.

Almirall, E., Lee, M. and Majchrzak, A. (2014), "Open innovation requires integrated competition-community ecosystems: Lessons learned from civic open innovation", Business Horizons, vol. 57, no. 3, p. 391-400.

Andreyeva, J.V. (2011), "The features of the hierarchical structure of the metropolis agglomerathions in the south of Russia" (in Russian), Architecture and Modern Information Technologies, vol. 16, no. 3, p. 10.

Angel, S., Parent, J., Civco, D.L., Blei, A. and Potere, D. (2011), "The dimensions of global urban expansion: Estimates and projections for all countries, 20002050", Progress in Planning, vol. 75, p. 53-107. 
Athey, G., Nathan, M., Webber, C. and Mahroum, S. (2008), "Innovation and the city", Innovation: Organization $\&$ Management, vol. 10, no. 2-3, p. 156-169.

Beauchemin, C. and Schoumaker, B. (2005), "Migration to cities in Burkina Faso: Does the level of development in sending areas matter?", World Development, vol. 33, no. 7, p. 1129-1152.

Beaverstock, J.V. (1994), "Re-thinking skilled international labour migration: world cities and banking organisations", Geoforum, vol. 25, no. 3, p. 323-338.

Boix, R., Veneri, P., Almenar, V. and Hernández, F. (2011), "Polycentric metropolitan areas in Europe: towards a unified proposal of delimitation" in E. Fernández-Vázquez \& F. Rubiera-Morollón (eds.) Defining the spatial scale in modern economic analysis, p. 45-70, Springer, Berlin.

Boussauw, K., van Meeteren, M., Sansen, J., Meijers, E., Storme, T., Louw, E. and Witlox, F. (2018), "Planning for agglomeration economies in a polycentric region: Envisioning an efficient metropolitan core area in Flanders", European Journal of Spatial Development, vol. 69, p. 1-26.

Brail, S. and Hussey, S. (2018), Citizen Engagement with the Changing City, Bang the Table.

Bredikhin, A.V. (2016), "The Rostov Agglomeration: Integration Development Priorities" (in Russian), Territorial Development Issues, vol. 34, no. 4. p. 5.

Butsch, C., Kumar, S., Wagner, P.D., Kroll, M., Kantakumar, L.N., Bharucha, E. and Kraas, F. (2017), "Growing 'smart'? Urbanization processes in the Pune urban agglomeration", Sustainability, vol. 9 no. 12, no. 2335.

Cattan, N. (2007), Cities and networks in Europe: a critical aproach to polycentrism, John Libbey Eurotext.

Chuanglin, F. and Danlin, Yu. (2017), "Urban agglomeration: An evolving concept of an emerging phenomenon", Landscape and Urban Planning, vol. 162, p. 126-136.

Concilio, G., Li, C., Rausell, P. and Tosoni, I. (2019), "Cities as enablers of innovation", in G. Concilio and I. Tosoni (eds.) Innovation Capacity and the City, p. 43-60, Springer, Cham.

Condon, P.M. (2019), Five Rules for Tomorrow's Cities: Design in an Age of Urban Migration, Demographic Change, and a Disappearing, Island Press.

Deutschmann, E. (2019), "Regionalisation and Globalisation in Networks of Transnational Human Mobility, 1960-2010", Società Mutamento Politica, vol. 10, no. 20, p. 139-154.

Druzhinin, A.G. (2013), "Spatial possibilities and barriers of the postindustrial development of a regional metropolis (the Case Study of Rostov-on-Don)", Regional Research of Russia, vol. 3. no. 4, p. 386-391.

Duranton, G. and Puga, D. (2004), "Micro-foundations of urban agglomeration economies", Handbook of Regional and Urban Economics, vol. 4, p. 2063-2117.

Fang, C. and Yu, D. (2017), "Urban agglomeration: An evolving concept of an emerging phenomenon", Landscape and Urban Planning, vol. 162, p. 126-136.

Ferraris, A., Santoro, G. and Papa, A. (2018), "The cities of the future: Hybrid alliances for open innovation projects", Futures, vol. 103, p. 51-60. 
Florida, R., Adler, P. and Mellander, C. (2016), "The city as innovation machine", Regional Studies, vol. 51, no. 1, p. 86-96.

Grübler, A. and Fisk, D. (eds.) (2013), Energising Sustainable Cities: Assessing Urban Energy, Routledge, Abingdon, United Kingdom.

Hu, C. (2017), Urban and Cluster Agglomeration Economies's Effects on Rural Households in Asia. Michigan State University.

Johansson, M., Nilsson, P. and Westlund, H. (2018), "Migration and Ageing in Expanding and Shrinking European Regions" in R.R. Stough, K. Kourtit, P. Nijkamp and U. Blien (eds.) Modelling Aging and Migration Effects on Spatial Labor Markets, p. 107-131, Springer, Cham.

Johnson, B. (2008), "Cities, systems of innovation and economic development", Innovation: Management, Policy \& Practice, vol. 10, no. 2-3, p. 146155.

Kovalev, O.I., Konstantinov, N.F. and Polozhiy, I.N. (2006), "Rostov region [Maps]: municipal districts and regional centers: atlas", Rostov-on-Don: Southern Aerogeodesic Enterprise.

Lu, L. (2019), "Study on the Mode of Yunnan County Economic Development Driven by the Construction of urban Agglomeration in Central Yunnan", Proceedings 9th International Conference on Education and Social Science (ICESS 2019), p. 191-196.

McCann, P. and van Oort, F. (2019), "Theories of agglomeration and regional economic growth: a historical review" in R. Capello and P. Nijkamp (eds.) Handbook of regional growth and development theories, Edward Elgar Publishing.

Merinov, Yu.N. and Merinova, Yu.Yu. (2014), "The Delimitation of Rostov Agglomeration" (in Russian), The Eurasian Scientific Journal, vol. 6, no. 25, p. 84. Mikhaylov, A., Mikhaylova, A. and Hvaley, D. (2020), "Spatial delimitation of Rostov agglomeration: data on geographical structure and transport accessibility", Mendeley Data, v1, 25 April 2020, shorturl.at/dDESU.

Mikhaylov, A.S., Mikhaylova, A.A. and Savchina, O.V. (2018), "Innovation security of cross-border innovative milieu", Entrepreneurship and Sustainability Issues, vol. 6, no. 2, p. 754-766.

Ni, P. (2008), Report of Chinese cities' competitiveness, Social Science Literature Press, Beijing.

Sementsov, S., Zavarikhin, S., Kurbatov, Y. and Pukharenko, Y. (2020), "Features of the formation of the St. Petersburg agglomeration by the beginning of the XX century", E3S Web of Conferences, vol. 164, no. 05009, EDP Sciences.

Stolarick, K. and Florida, R., (2006), "Creativity, connections and innovation: a study of linkages in the Montréal Region", Environment and Planning A: Economy and Space, vol. 38, no. 10, p. 1799-1817.

Tabuchi, T. (2013), "Agglomeration in world cities", Procedia-Social and Behavioral Sciences, vol. 77, p. 299-307.

Tomalty, R. and Mallach, A. (2015), Changing World, Changing Cities, Island Press/Center for Resource Economics.

United Nations (2019), Population Division World Urbanization Prospects: The 2018 Revision, Department of Economic and Social Affairs, New York. 
Verstraten, P. Verweij, G. and Zwaneveld, P.J. (2019), "Complexities in the spatial scope of agglomeration economies", Journal of Regional Science, vol. 59, no. 1, p. 29-55.

Wang, F., Wei, X., Liu, J., He, L. and Gao, M. (2019), "Impact of high-speed rail on population mobility and urbanisation: A case study on Yangtze River Delta urban agglomeration, China", Transportation Research Part A: Policy and Practice, vol. 127, p. 99-114.

Ye, C., Zhu, J., Li, S., Yang, S. and Chen, M. (2019), "Assessment and analysis of regional economic collaborative development within an urban agglomeration: Yangtze River Delta as a case study", Habitat International, vol. 83, p. 20-29. 